\title{
<合同シンポジウムI >
}

1) 病理

\section{頚動脈硬化の病理}

\author{
益田 順一1) 緒方 絢 ${ }^{21}$ \\ ${ }^{1)}$ 島根大学医学部臨床検查医学 \\ ${ }^{2)}$ 枚方療育園
}

Key words : 動脈原性塞栓, 粥腫塞栓, 頚動脈内膜剥離術, 血管形成術, ステント

(脳卒中 $26: 614-616,2004$ )

\section{はじめに}

頚動脈のアテローム硬化性病変は, 内腔の狭窄や血 栓形成などを介して直接, 脳梗塞の責任血管病変と なっているばかりでなく, 脳梗塞の発症予防のために 行われている頸動脈の血行再建術（内膜剥離術や血管 形成術）に伴って発生する粥腫塞栓による脳梗塞の発 生要因ともなる病変である。本稿では, 頚動脈硬化病 変を基盤にして発生する動脈原性脳塞栓症の病理と発 症メカニズムについて考察する。

\section{1. 頸動脈硬化による脳梗塞の病理学的特徵}

頝動脈硬化を基盤にして発生する脳梗塞では，灌流 域の末梢領域いわゆる Borderzone に脳梗塞が多発す ることが知られており，その機序として 3 つの仮説が 提唱されている. 第一は, 頸動脈のアテローム硬化と 血栓形成によって血管内腔の狭窄が抢こる結果，灌流 域に血流不全がおこるもので Distal perfusion failure と呼ばれ血行力学的変化の影響をうけやすい灌流域の 末梢領域に脳梗塞がおこるとする仮説である．第二の 仮説は, 動脈原性塞栓症 (Artery-to-artery embolism) の機序で, 莖動脈壁から遊離し，断片化した血栓が皮 質枝の内径の小さな末梢動脈にロッジするために， Borderzone に脳梗塞が拈きてくるとする仮説である. 第三の仮説は, Caplan らが提唱した塞栓クリアランス 障害 Impaired clearance (washout) of emboli で, 血流 不全に陥った部位ではロッジした栓子が血流によるク リアランスがされにくいことから, Distal field perfusion failure と. Artery-to-artery embolism 2 2つの機 序の両者が関与して Borderzone に脳梗塞がおきてく
るとする仮説である".

しかしながら，実際には，頝動脈硬化を基盤にして 発生する脳梗塞は, Borderzone の脳梗塞ばかりでな く, Arterial territorial infarct の症例も多くみられる ばかりでなく，一部にはラクナ梗塞もあり，多様な脳 梗塞のパターンが存在することが明らかにされてい 万.

\section{2. 弹腫塞栓による脳梗塞の病理学的検討}

動脈原性脳塞栓症の特徽を塞栓物質としてのコレス テリン結晶に着目して病理学的に調べた我々の成績で は, 郡腫塞栓による脳梗塞を大きく2つのタイプにわ けることができだ2. 一つは中大脳動脈と前大脳動脈, あるいは, 中大脳動脈と後大脳動脈の灌流領域の Borderzone に梗塞が多発性に分布しているタイプで 9 例 あった。組織学的には，コレステリン結晶を主要な成 分とする Cholesterol crystal emboli が，皮質表面に分 布する比較的小さい径の皮質枝動脈に認めらた。もう 一つのタイプは動脈灌流域梗塞で，6症例見いだすこ とができた。このタイプでは主幹動脈あるいは比較的 大きな動脈に Atheroemboli が認められ，栓子内には コレステリン結晶以外にもアテロームの組織成分や フィブリンや血小板などの血栓成分を多く含んでおり 比較的大きな栓子だった.

このような强腫塞栓の大きさと分布は, Massachusetts General Hospital からも報告されているが32，わ れわれの検討ではさらに柅腫塞栓は閉塞血管の太さに よって塞栓の棈成成分に違いがみられ, 新腫塞栓の中 にみられるCholesterol crystal 以外の成分，とくに フィブリンのしめる割合が多くなるとロッジする血管 
径が大きくなる傾向を示していた，従って，粥腫塞栓 の構成成分とその壊れやすさが栓子のロッジする血管 の径を決める要因となって脳梗塞の分布と広がりを決 める要因となっていることや, 栓子の断片化と移動に よる re-opening や出血性梗塞の出現の要因にもなっ ているのではないかと考えらた.

\section{3. 塞栓性機序によるラクナ梗塞}

ラクナ梗塞は, 脳の樑部に好発する径 $1.5 \mathrm{~cm}$ 以下の 脳梗塞で, その責任血管病変は, 脳内の小細動脈の硝 子化, 線維化, あるいは, 血管壊死の血栓性閉塞やそ の器質化によるもので, small vessel disease と呼ばれ ている.ところが, 近年, DiffusionMRIが出現し, 急 性期のラクナ梗塞が古い病巣と区別して描出されるよ うになったことから，アテローム血栓性機序や心原性 塞栓症によるラクナ梗塞の存在が明らかになってき た4)5. その結果, ラクナ梗塞の中にも，アテローム硬 化を基盤にした動脈原性脳塞栓, あるいは, 心原性脳 塞栓の機序で発生しているものがあることが明らかに なってきた. 従って, 大脳深部小梗塞であってもアテ ローム血栓性機序の可能性を含めて責任血管病変の検 索を進める必要がある。

\section{4. 頚動脈の血行再建術に伴う脳梗塞の発症機序}

頸動脈内膜剥離術が脳梗塞の発症予防に有効である ことが, randomized prospective study で証明されて いるが,一方で 2 8\% 程度の頻度で周術期に脳梗塞が おこるリスクがあることも明らかにされている，この リスクを減少させることを目的として，経皮的にカ テーテルを用いて血管形成術が行われるようになった が，その成績は内膜剥離術に比べて必ずしも向上がみ られず，血管形成術による血管の拡張操作が末梢動脈 に塞栓を惹起するリスクをむしろ増加させている可能 性も指摘されている. Ohki らは，外科的に切除された 䅡動脈内膜を用いて, exvivo でバルーンやステント を用いて血管形成術を行い，灌流液から塞栓物質を回 収して検索を行ったところ, echolucent plaque で $90 \%$ 以上の高度狭窄のあった頚動脈では塞栓物質が多く認 められ，塞栓物質は atherosclerotic debris，organized thrombus, calcified material から成っていたと報告 している゙. Manninen らは, cadaverを用いて実験を 行い, バルーンやステントによる血管拡張によって, 頝動脈のプラークの被膜に裂け目が生じ，アテローム の破綻を抗こすことをMRI 病理組織学的方法に
よって証明している7゙.

最近，このような血管形成術中の末梢動脈への塞栓 を予防する目的で distal protection deviceを用いたス テント術が行われるようになり，その成績がいくつか 報告されている クを臨床的に減少させうる可能性を示しているばかり でなく, 回収した塞栓物質を病理組織学的に観察して, アテロームの中心に存在する壊死物質や脂質, 泡沫細 胞，血栓，石灰化物質からできていること，その大き さは多くは $1 \mu \mathrm{m}$ から $1 \mathrm{~mm}$ 程度で多様で, 一部では数 $\mathrm{mm}$ ほどの大きさのものもあり，大きなばらつきがあ ることなどを示した。このような成績は，前述した栓 子の成分とこわれやすさが栓子のサイズとロッジする 血管の大きさと分布を決める要因となり, 多様な脳梗 塞の大きさや病理学的な分布を左右するという我々の 仮説を裏付ける成績であった。

\section{結語}

1. 頚動脈のプラークの破綻による潰瘍形成や血栓 形成, あるいは大きな lipid coreの形成が distal embolization や血行再建術の際の合併症のリスクになっ ている.

2. distal embolization は, 境界域梗塞に限らず, 動 脈灌流域梗塞やラクナ梗塞の原因となる.

3. 塞栓の構成成分と壊れやすさが栓子のサイズや ロッジする動脈の大きさを決め, 脳梗塞の大きさや病 理学的分布を決める要因になっている.

4. 血管形成術やステントは, プラークの被膜を破壊 し, 洌腫成分の塞栓をおこす可能性が高い。

5. 塞栓物質を回収する装置は, 栓子を回収除去する ことができ，合併症の発生を減少させるために有効な 手段となる可能性が高い. 栓子の大きさは多様で，ア テローム組織あるいは血栓性分に由来しており，その 構成成分も多様である.

6. 䅡動脈のエコーや MRI を行って, アテロームの 組織学的構築を事前に解析することが塞栓のリスク評 価に有用な手段となると考えられる.

\section{文献}

1) Caplan LR, Hennerici M. Impaired clearance of emboli (washout) is an important link between hypoperfusion, embolism, and ischemic stroke. Arch Neurol $55 ; 1475-82,1998$

2) Masuda J, Yutani C, Ogata J, et al : Atheromatous 
embolism in the brain: A clinicopathologic analysis of 15 autopsy cases. Neurology $44: 1231,1994$

3) Ezzeddine MA, Primavera JM, Rosand J, et al. Clinical characteristics of pathologically proved cholesterol emboli to the brain. Neurology 54 : $1681-1683,2000$

4) Baird AE, Lovblad KO, Schlaug G, et al. Multiple acute stroke syndrome : marker of embolic disease? Neurology 54 : 674-678, 2000

5) Yonemura K, Kimura K, Minematsu K, et al. Small centrum ovale infarcts on diffusionweighted magnetic resonance imaging. Stroke $33: 1541-1544,2002$

6) Ohki T, Marin ML, Lyon RT, et al. Ex vivo human carotid artery bifurcation stenting : Correlation of lesion characteristics with embolic potential. J Vasc Surg 27 : 463-471, 1998

7) Manninen HI, Rasanen HT, Vannien RL, et al.
Stent placement versus percutaneous transluminal angioplasty of human carotid arteies in cadavers in situ : Distal embolization and findings at intravascular US, MR imaging, and Histopathologic analysis. Radiology 212:483-492, 1999

8) Tubler T, Schluter M, Dirsch O, et al. Balloonprotected carotid artery stenting. Relationship of periprocedural neurological complications with the size of particulate debris. Circulation 104 : 2791-2796, 2001

9) Angelini A, Reimers B, Barbera MD, et al. Cerebral protection during carotid artery stenting. Collection and histopathologic analysis of embolized debris. Stroke 33 : 456-461, 2002

10) Whitlow PL, Lylyk P, Londero $H$, et al. Carotid artery stenting protected with an emboli containment system. Stroke 33 : 1308-1314, 2002

\section{Abstract \\ Pathology of carotid artery sclerosis}

Junichi Masuda, M.D. ${ }^{1)}$ and Jun Ogata, M.D. ${ }^{2)}$

${ }^{1)}$ Department of Laboratory Medicine, Shimane University School of Medicine, ${ }^{2)}$ Hirakata-Ryoikuen

Carotid atherosclerosis is resoponsible for atherothrombotic brain infarcts. Plaques with an ulcerated cap and overlying thrombus and those with a large lipid core may be more susceptible to distal embolisation and complication during carotid endarterectomy and angioplasty with stenting. Distal embolisation may lead to a variety of new ischemic brain lesions, including borderzone, arterial territorial, and lacunar infarcts. This diversity of the lesion appeared to be correlated with histologic features of the embolic materials (cholesterol crystal with or without other atheromatous components, fibrin, or platelets). This variation in the components of the emboli may determine the size and location of the lodged arteries and feasibility of re-opening and hemorrhagic transformation. Distal protection devices trap and divert many emboli seen with this procedure and therefore effectively prevent cerebral complication. Duplex and MRI of carotid artery may be useful for determining the risks of endovascular intervention within individual patients according to plaque morphology.

(Jpn J Stroke 26:614-616, 2004)

Key words : Artery-to-artery embolism, Atheromatous embolism, Carotid endarterectomy, Angioplasty, Stent 